\title{
FUNCTIONING OF SPORT AND RECREATION FACILITIES OF THE CITY OF POZNAŃ IN THE OPINION OF SERVICE PROVIDERS
}

\author{
EWA KRUSZYŃSKA, ${ }^{1}$ L'UDMILA JANČOKOVÂ, ${ }^{2}$ \\ ELŻBIETA SIEŃKO-AWIERIANÓW ${ }^{3}$
}

\author{
1 University of Szczecin \\ Faculty of Physical Culture and Health Promotion \\ Department of Individual Sports, Tourism and Recreation \\ e-mail: e.m.kruszynska@gmail.com \\ 2 Matej Bel University, Banská Bystrica \\ Faculty of Arts \\ Department of Physical Education and Sports \\ e-mail: Ludmila.Jancokova@umb.sk \\ 3 University of Szczecin \\ Faculty of Physical Culture and Health Promotion \\ Department of Human Functional Anatomy and Biometry \\ e-mail: ela.sienko@wp.pl
}

\section{JEL CODES}

KEYWORDS

ABSTRACT

\section{L83, L88, I15}

sport and recreation infrastructure, management of sport and recreation facility, interview survey

Management of a sport and recreational facility aims at effective use of potential of a given infrastructure. Today, a sport and recreation facility must be not only technically modern, but also adapted to the changing needs of the customers. The disparity between goals set by service providers stems from the fact that efforts are made, on the one hand, to achieve satisfaction from financial results, and on the other, to implement the social objective of a sport and recreation facility that may contravene rational efficiency and economic performance.

The aim of this article was the evaluation of sport and recreation facilities by people managing them within Poznan in the aspect of the economic factor, competitiveness, and policy pursued in the sport and recreation sector by the authorities of the Poznan City Hall. In order to achieve this aim, interview surveys were conducted among 38 people managing selected sport and recreation facilities. The performed statistical analysis shows that that all factors studied are important in the proper functioning of sport and recreation facilities. The determination of service prices is mostly affected by the costs of running a sport and recreation facility and prices offered by competition. A point of concern is that only $40 \%$ of the respondents positively evaluated the policy conducted by the City Council in the sports and recreation sector. 


\section{Introduction}

Management of sport and recreation facility aims at effective use of the potential brought about by a given infrastructure. The definition of "object management" currently has a much broader meaning than the definition regulated by the provisions of the act, as it concerns not only real estate administration, but also, and perhaps above all, business and commercial management. Today, a sport and recreation facility must be not only technically modern but also adapted to the changing needs of customers. Each type of sport and recreation infrastructure has its own specific business model (Dębski, Kozłowski, Wawrzak, 2010).

The disparity between goals set by service providers stems from the fact that efforts are made, on the one hand, to achieve satisfaction from financial results, and on the other, to implement the social objective of a sport and recreation facility that may contravene rational efficiency and economic performance.

Liberalisation of service sector in Poland, increased competition on the market of sports and recreation services, growing awareness of customers and their requirements towards service providers result in an increasing interest of service providers in opportunities to obtain and maintain a competitive advantage on this market. Thus, sport and recreation facilities are more and more often applying various methods of competition to win the client (service recipients), while remembering that price, which was until recently a commonly used instrument of influence, unfortunately no longer plays such an important role in obtaining a competitive advantage by a sport and recreation facility. Competitiveness should be based on high quality of services, which undoubtedly constitutes a solid basis for building long-term relationships with the service recipient (Widawska-Stanisz, 2015).

The aim of this article was the evaluation of sport and recreation facilities by people managing them within Poznan in the aspect of the economic factor, competitiveness, and policy pursued in the sports and recreation sector by the authorities of the Poznań City Hall.

\section{Research materials and methods}

In order to achieve the aim of the article, interview surveys were conducted (method of structured interview). The non-probability sampling of respondents, i.e. managers in selected all-season sport and recreation facilities, was conducted. In total, 38 respondents were included in the study. The questions included in the questionnaire and addressed to service providers were aimed at obtaining their opinion on the operation of sport and recreation facilities under their management in the aspect of the economic factor, competitiveness and policy pursued in the sports and recreation sector by the authorities of the Poznań City Hall.

The following research methods were used to conduct the analysis of the studied phenomena: descriptive statistics, histograms, medium equality testing (ANOVA), testing equality of variance (test), Pearson's Chi^2 test, as well as conditional probability and model of binary variables. 


\section{Research results}

Based on the service providers' answers to the questions, it can be concluded that there is a connection between a service provider, i.e. a person who manages a sport and recreation facility, and an organization system (the owner of the facility: private, public), which significantly affects the functioning of the sports and recreation infrastructure of the city of Poznan, as well as the system of organization of sport and recreation facilities.

In the questionnaire, the respondents were asked if, and to what extent, they perceive the competitive activities of sport and recreation facilities operating in Poznań.

Statistical characteristics indicate that service providers are aware of the existence of competition among sport and recreation facilities (above average perceptibility value). However, at the same time, the results (especially standard deviation and kurtosis) indicate a wide diversity of service providers' opinions (tab. 1). The distribution presented in the figure below resembles a multimodal distribution with local maxima - the level of perceptibility most often indicated by service providers for the values of 4, 6 and 8 (fig. 1).

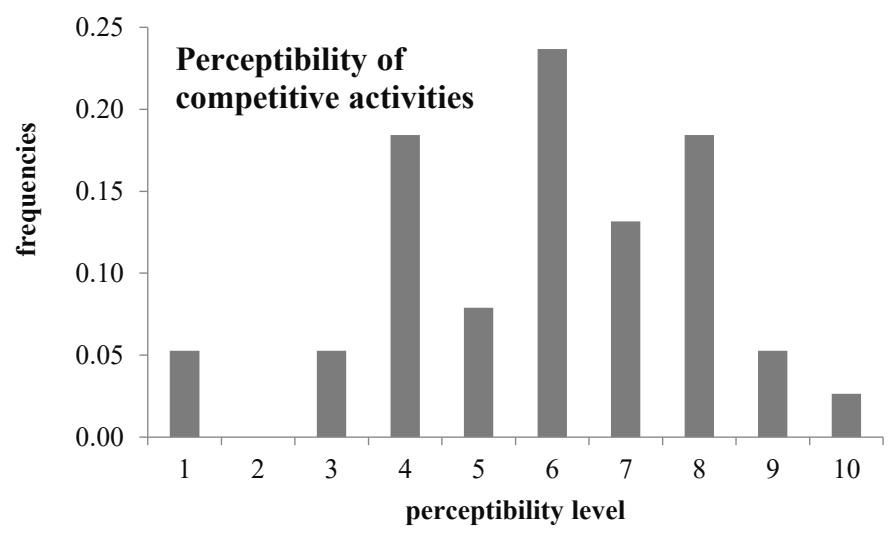

Figure 1. Perceptibility of competitive activities of sport and recreation facilities in the opinion of service providers Source: own work.

Table 1. Statistical characteristics of the perceptibility of competitive sport and recreation facilities, in the opinion of service providers

\begin{tabular}{|l|c|c|c|c|c|}
\hline & $\bar{X}$ & $\mathrm{~S}$ & $\mathrm{SK}$ & $\mathrm{K}$ & $\mathrm{N}$ \\
\hline Competitors' activities & 5.895 & 2.115 & -0.381 & 2.766 & 38 \\
\hline
\end{tabular}

Source: own work. 
An important element of the analysis of the participation of Poles in sports and physical recreation is the analysis of expenses incurred for sports and recreation purposes. The results of surveys conducted by the Central Statistical Office (GUS) in 2017 show that among all households surveyed, only $41.1 \%$ incurred any costs for this purpose. Financial resources intended for sports and recreational activities (without travel costs) were allocated by $29.9 \%$ of households.

As compared to 2008 , this percentage increased by $12 \%$. The most visible are changes in expenses related to the payment for sports and recreational activities (in $2008-17.2 \%$ of households, in $2017-29.9 \%$ of households), and the purchase, maintenance or rental of sports equipment (in $2008-12.6 \%$, in 2017 - 19.4\%). Moreover, there can be observed an increase in the average total amount of expenditure per household in Poland over the period of 12 months studied - from PLN 284 in 2008 to PLN 418 in 2017, mainly due to a significant increase in the number of households incurring such expenses. The average expenses in households that incurred any costs for sports and recreational purposes amounted to PLN 1017 (per household incurring expenditure), in comparison to 2008, when they increased by only PLN 42. Among the examined households, the largest costs were related to sports and recreational activities (PLN 818) (GUS, 2018).

Another question addressed to the service providers concerned determination of the level of perceptibility of changes in the household budgets of service recipients.

Statistical characteristics indicate a slightly above average level of perceptibility of changes (as the average shows); however, the shape analysis, especially of negative skewness, indicates the most-distinguished categories with a high level of perceptibility. This proves the great importance of the perceptibility of changes in the household budgets of service recipients, clearly felt by service providers. The consequence of this should be proper planning of the rules for the proper functioning of sport and recreation facilities by service providers (fig. 2, tab. 2).

Table 2. Statistical characteristics of perceptibility of changes in household budget of service recipients, in the opinion of service providers

\begin{tabular}{|l|c|c|c|c|c|}
\hline & $\bar{X}$ & $\mathrm{~S}$ & $\mathrm{SK}$ & $\mathrm{K}$ & $\mathrm{N}$ \\
\hline $\begin{array}{l}\text { Perceptibility of changes in household } \\
\text { budget of service recipients }\end{array}$ & 5.789 & 2.350 & -1.226 & 3.702 & 38 \\
\hline
\end{tabular}

Source: own work.

Sport and recreation facilities in their pricing policy must adapt to the expectations of the service recipient. For sport and recreation facilities, the price level is important because it determines the income in the facility as well as the demand. The price level may also be information for the service recipient about the quality and value of services. It may also affect the image of sport and recreation facilities.

Confirmation of this opinion was reflected in the answers to the question determining the level of price adjustment by service providers to the expectations of service recipients using sport and recreation facilities. It is visible that price is an important criterion for service providers. This 
is confirmed by the high average score of the price adjustment level to the recipients as well as the small dispersion of the opinions of the service providers under review (fig. 3, tab. 3).

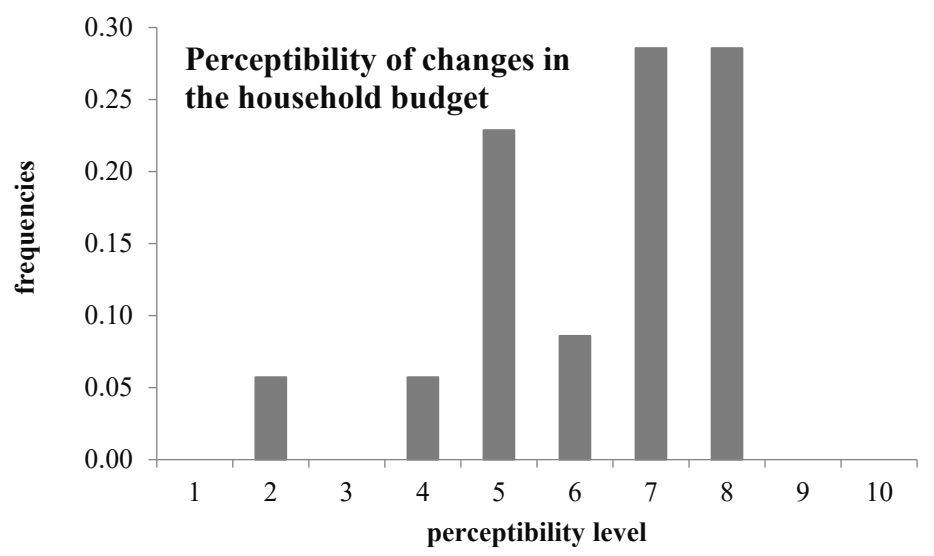

Figule 2. Perceptibility of changes in the household budgets of service recipients, in the opinion of service providers

Source: own work.

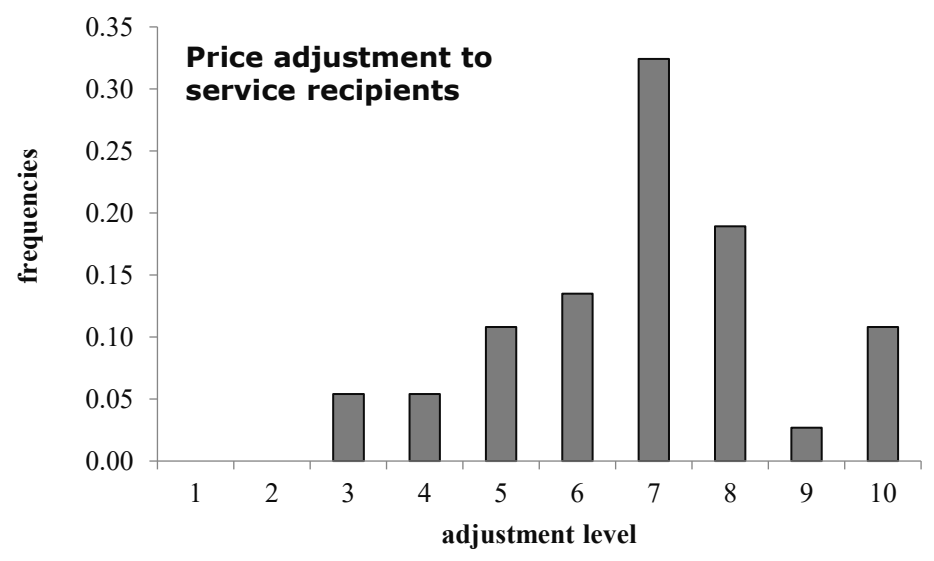

FigulP 3. Adjusting the price to the expectations of service recipients, in the opinion of service providers Source: own work. 
Table 3. Statistical characteristics of adjusting price to the expectations of service recipients in the opinion of service providers

\begin{tabular}{|l|c|c|c|c|c|}
\hline & $\bar{X}$ & S & SK & K & N \\
\hline $\begin{array}{l}\text { Adjusting price to the expectations } \\
\text { of service recipients }\end{array}$ & 6.658 & 2.096 & -0.805 & 4.323 & 38 \\
\hline
\end{tabular}

Source: own work.

A service is a commissioned job and benefit aimed at enriching personal values or volume of utility values that a service recipient has (Rogoziński, 2000). According to Adrian Payne, a service is an activity that includes an element of intangibility that affects a client, as well as objects or property in their possession, and which does not include a transfer of ownership. Transfer of ownership may, however, take place, and the provision of a service may or may not be closely related to the material good. In summary, a service is simply an activity performed by a service provider to meet the needs or expectations of a service provider (Payne, 1996).

It is obvious that all kinds of sport and recreation services are associated mainly with sport or physical activity. In the case when the use of a sports facility, ground or an instructor's services involves payment, non-competitive sport becomes a sports and recreation service. Competitive sport, on the other hand, includes adolescents and adults with full physical strength who, through systematic exercises, will improve their movement skills, bringing their bodies to the highest physical efficiency (Trześniowski, 2000). From the point of view of a professional athlete, competitive sport is a profession, whereas from the viewer's point of view, it is a sports and recreation service. Examples of sports and recreation services are: services provided by fitness centres, swimming pools, tennis courts, golf courses. The availability of sports and recreation services can be analysed in various aspects: economic, social and spatial. In this study, when considering the availability of services across the city, all three factors were considered.

According to the surveyed service providers, sports and leisure services offered in the whole city are at a high level of accessibility. This is illustrated through the presented statistical characteristics and the figure describing the shape of the distribution of the variable under study - the average value combined with the negative skewness and the very high degree of kurtosis in this case. It is also confirmed by the shown graph where over $50 \%$ of all grades fall on ratings between 7-10. The availability of sports and recreation services assessed by service providers in this way proves that in their opinion the facilities they manage function at a high level of organization. (fig. 4, tab. 4). 


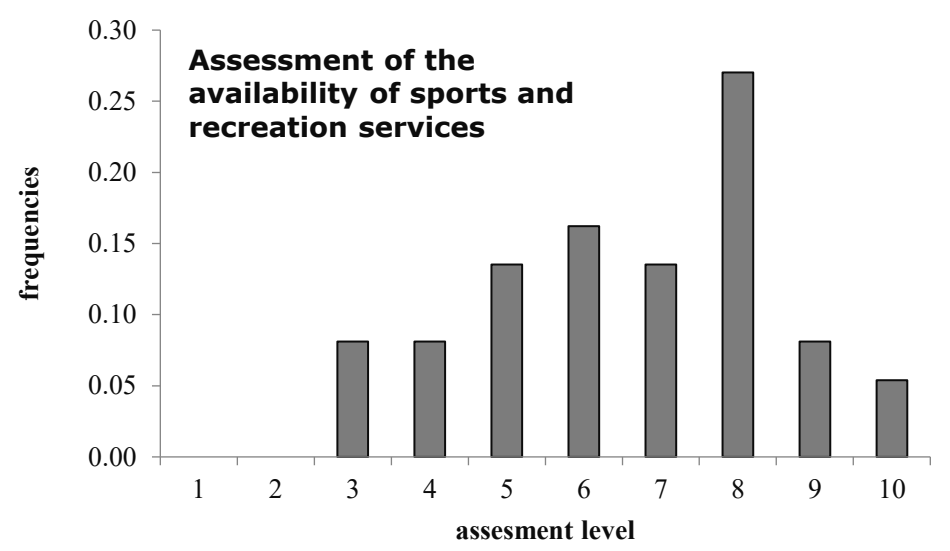

Figure 4. Assessment of the availability of sports and recreation services in Poznań in the opinion of service providers

Source: own work.

Table 4. Statistical characteristics of the availability of sports and recreation services in Poznań in the opinion of service providers

\begin{tabular}{|l|c|c|c|c|c|}
\hline & $\bar{X}$ & S & SK & K & N \\
\hline $\begin{array}{l}\text { Availability of sports and recreation } \\
\text { services }\end{array}$ & 6.421 & 2.189 & -0.676 & 3.335 & 38 \\
\hline
\end{tabular}

Source: own work.

Subjective perception of sports and recreation facilities located in the city of Poznan was assessed based on four questions asked to service providers in a questionnaire. Their opinion is shown graphically in figure 5. The most important factor for service providers for the proper functioning of a sport and recreation facility is the adjustment of the price of services to the expectations of service recipients ( $X=6.658)$. Almost the same importance is attributed to the availability of sports and recreation services throughout the city $(X=6.421)$. The importance of competition in sport and recreation facilities was assessed slightly lower ( $X=5.895)$, with changes in personal budgets of service recipients ( $X=5.789$ ) being placed on a similar level of sensibility (fig. 5).

Visible lack of statistically significant differences between the averages of the variables examined indicates that the importance of each of them is assessed similarly high by service providers. Moreover, according to service providers all have a significant meaning in the proper functioning of sports and recreation facilities they manage. 


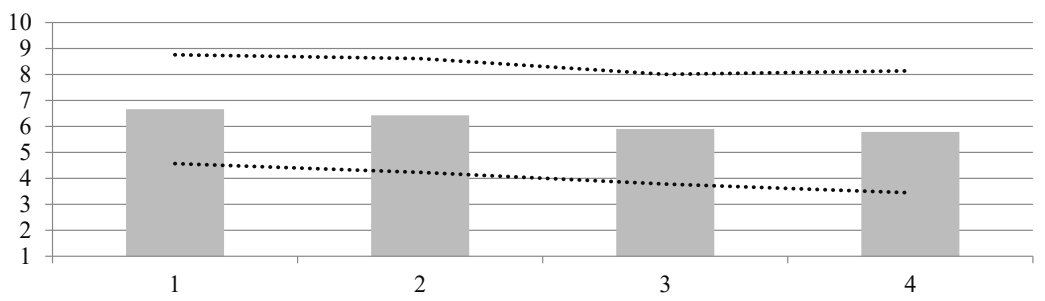

Figure 5. Graphic picture of the assessment of the proper functioning of sport and recreation facilities $-\bar{X} \pm \mathrm{S}$

1. Price adjustment to a service recipient

2. Availability of sports and recreation services in the city

3. Actions taken by competitive sport and recreation facilities

4. Changes in household budgets of service recipients

Source: own work.

Subjective perception of sport and recreation facilities in the city of Poznań was also expressed by service providers in answers to specific questions requiring only YES or NO answer (tab. 5).

From the list of responses of the surveyed service providers presented below, it appears that the criteria they consider when fixing prices in the sport and recreation facilities managed by them constitute:

- mark-up on costs (cost + margin) $-84.2 \%$ of YES answers,

- changes in household budgets of service recipients $-81.5 \%$ of YES answers,

- costs of running a sport and recreation facility $-89.4 \%$ of YES answers,

- prices at competitive facilities $-84.2 \%$ of YES answers.

The obtained results are consistent with information presented in the literature on the subject and indicate the correct direction in the management of the examined sport and recreation facilities, in the scope of implementing the right pricing policy.

Table 5. Opinion of service providers assessing the functioning of sports and recreation facilities

\begin{tabular}{|l|c|c|}
\hline \multicolumn{1}{|c|}{ Variables tested } & Number of YES answers & Number of NO answers \\
\hline $\begin{array}{l}\text { Determining prices based on mark-up on costs (cost } \\
+ \text { margin) }\end{array}$ & 32 & 6 \\
\hline Perception of changes in household budgets of & $84.2 \%$ & 7 \\
service recipients & 31 & $18.4 \%$ \\
\hline The costs of running a sport and recreation facility & $81.5 \%$ & 4 \\
determine the price of services in the facility & 34 & $10.5 \%$ \\
\hline When determining prices in a sport and recreation & $89.4 \%$ & 6 \\
facility, you compare prices at competitive facilities & 32 & $15.7 \%$ \\
\hline
\end{tabular}

Source: own work.

Table 6 contains results of Pearson's Chi^ 2 test with the help of which attempts were made to determine the relations between the variables contained in the above questions and the influence of selected dependencies on the functioning of sport and recreation facilities. 
Statistically significant at $\mathrm{p}<0.05$ were only dependencies between: price determination (cost + margin) and costs of running a sport and recreation facility (variable 2); and between price fixing (cost + margin) and prices of services in competitive sport and recreation facilities (variable 4).

Statistically insignificant were dependencies between: perceptibility of changes in household budgets of service recipients and prices of services in competitive sport and recreation facilities (variable 1), as well as between perceptibility of changes in household budgets of service recipients and costs of running a sport and recreation facility (variable 3). The list of selected dependencies allows for believing that the pricing of services in sport and recreation facilities is primarily affected by the costs of running a sport and recreation facility and fixed prices in competitive sport and recreation facilities in the city of Poznań.

Table 6. Influence of selected dependencies on the functioning of sport and recreation facilities $\mathrm{p}<0.05$

\begin{tabular}{|l|c|c|}
\hline \multicolumn{1}{|c|}{ Variables } & Df & Pearson's Chi^2 \\
\hline $\begin{array}{l}\text { 1. Perception of changes in household budgets of service recipients and prices of services in } \\
\text { competitive sport and recreation facilities }\end{array}$ & 1 & 0.507 \\
\hline 2. Price fixing (cost + margin) and costs of running a sport and recreation facility & 1 & $\mathbf{0 . 0 4 7}$ \\
\hline $\begin{array}{l}\text { 3. Perception of changes in household budgets of service recipients and costs of running } \\
\text { a sport and recreation facility }\end{array}$ & 1 & 0.572 \\
\hline $\begin{array}{l}\text { 4. Price fixing (cost + margin) and prices of services in competitive sport and recreation } \\
\text { facilities }\end{array}$ & 1 & $\mathbf{0 . 0 0 4}$ \\
\hline
\end{tabular}

Source: own work.

The answers of the service providers to questions evaluating the policy in the field of sports and recreation implemented by the Poznan City Hall and its impact on the functioning of sport and recreation facilities gave disturbing results (tab. 7). The data presented on the policy implemented by the City Hall show that it meets the expectations of service providers only in about $40 \%$.

Tahle 7. Opinion of service providers assessing the policy implemented in the sports and recreation sector by the Poznań City Hall

\begin{tabular}{|c|c|c|}
\hline Variables tested & Number of YES answers & Number of $\mathrm{NO}$ answers \\
\hline $\begin{array}{l}\text { Policy implemented by the Poznan City Hall has a positive effect on the } \\
\text { functioning of sport and recreation facilities }\end{array}$ & $\begin{array}{c}15 \\
39.4 \%\end{array}$ & $\begin{array}{c}23 \\
60.5 \%\end{array}$ \\
\hline Policy implemented by the Poznan City Hall is effective & $\begin{array}{c}15 \\
39.4 \%\end{array}$ & $\begin{array}{c}23 \\
60.5 \%\end{array}$ \\
\hline
\end{tabular}

Source: own work.

\section{Conclusions}

For several years, dynamic development of sports and recreation infrastructure in Poland has been observed. Currently, the biggest problem is management at the appropriate level of these facilities, which requires employment of professional staff in the broadly understood management of sports properties. Therefore, service providers are required to combine managerial competences with 
knowledge of physical culture and sport (Ministerstwo Sportu i Turystyki, 2017). Effective management allows for taking full advantage of the potential that the infrastructure brings. Hence, the opinion of service providers on the functioning of sport and recreation facilities in various aspects is very important.

This study assesses the functioning of sports and recreation facilities in the opinion of service providers, based on the assessment of the economic factor, competitiveness and policy pursued by the authorities of the Poznan City Hall. The statistical analysis shows that the managers of sport and recreation facilities appreciate the importance of each of these factors and, in their opinion, all of them are important in the proper functioning of sport and -recreation facilities they manage. The use of selected dependencies confirmed that the pricing of services in sport and recreation facilities by service providers is primarily affected by the costs of running a sport and recreation facility and prices in competitive sport and recreation facilities in the city of Poznań. The response of service providers to the question evaluating the policy in the sports and recreation sector implemented by the Poznań City Hall gave disturbing results, as according to them, it meets their expectations only in $40 \%$.

\section{References}

Dębski, K., Kozłowski, K., Wawrzak, K. (2010). Zarządzanie obiektami sportowo-rekreacyjnymi. Dobre Praktyki PPP. GUS (2018). Uczestnictwo Polaków w sporcie i rekreacji ruchowej w 2017r. Warsaw.

Ministerstwo Sportu i Turystyki. (2017). Najlepsze praktyki: zarzadzanie obiektami sportowymi. Warsaw: IREM.

Payne, A. (1996). Marketing ustug. Warsaw: Polskie Wydawnictwo Ekonomiczne.

Rogoziński, K. (2000). Ustugi rynkowe. Poznań: Akademia Ekonomiczna w Poznaniu.

Trześniowski, R. (2000). Wychowanie fizyczne a sport. In: K. Zuchory (ed.), Myśli i uwagi o wychowaniu fizycznym i sporcie (pp. 48-60). Warsaw: Akademia Wychowania Fizycznego w Warszawie.

Widawska-Stanisz, A. (2015). Jakość usług sportowo-rekreacyjnych. Quality in Sport, 1, 65-75. 


\section{FUNKCJONOWANIE OBIEKTÓW SPORTOWO-REKREACYJNYCH MIASTA POZNANIA W OPINII USŁUGODAWCÓW}

SŁOWA KLUCZOWE

STRESZCZENIE infrastruktura sportowo-rekreacyjna, zarządzanie obiektem sportowo-rekreacyjnym, badania ankietowe

Zarządzanie obiektem sportowo-rekreacyjnym ma służyć efektywnemu wykorzystaniu potencjału, który niesie ze sobą dana infrastruktura. Obecnie obiekt sportowo-rekreacyjny musi być nie tylko nowoczesny pod względem technicznym, ale musi dostosować się do zmieniających się potrzeb klientów. Rozbieżność celów stawianych przed usługodawcami polega na tym, że wymusza się dążenia z jednej strony do osiągania satysfakcji z wyników finansowych a z drugiej do realizacji społecznego celu działania obiektu sportowo-rekreacyjnego, który może okazać się sprzeczny z racjonalnym efektywnościowym i ekonomicznym działaniem.

Celem pracy była ocena funkcjonowania obiektów sportowo-rekreacyjnych przez osoby zarządzające danym kompleksem na terenie miasta Poznania, w aspekcie czynnika ekonomicznego, konkurencyjności i polityki prowadzonej w sektorze sportu i rekreacji przez władze Urzędu Miasta Poznania. Dla realizacji celów pracy przeprowadzono badania ankietowe wśród 38 osób zarządzających wybranymi obiektami sportowo-rekreacyjnymi.

Z dokonanej analizy statystycznej wynika, że wszystkie badane czynniki mają znaczenie w prawidłowym funkcjonowaniu obiektów sportowo-rekreacyjnych. Na ustalanie cen usług największy wpływ mają koszty prowadzenia obiektu sportowo-rekreacyjnego oraz ceny w konkurencyjnych placówkach. Niepokojący jest fakt, iż tylko $40 \%$ badanych pozytywnie oceniło politykę prowadzoną przez Urząd Miasta w sektorze sportu i rekreacji. 